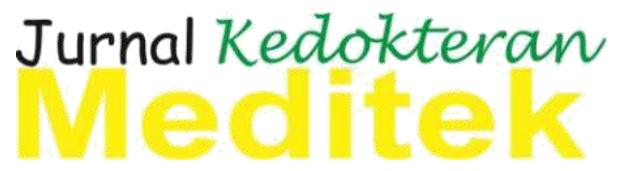

p-ISSN : 2686-1437

e-ISSN : 2686-0201

http://ejournal.ukrida.ac.id/ojs/index.php/Meditek/index

\title{
Deteksi Bakteri Coliform pada Es Batu yang Disajikan di Tempat Makan Tenda di Kecamatan Grogol Petamburan
}

\author{
Chrysilla Dita ${ }^{1}$, Donna Mesina Rosadini Pasaribu², Nicolas Layanto ${ }^{2}$ \\ ${ }^{1}$ Fakultas Kedokteran dan Ilmu Kesehatan Universitas Kristen Krida Wacana, Jakarta, Indonesia \\ ${ }^{2}$ Departemen Mikrobiologi Fakultas Kedokteran dan Ilmu Kesehatan \\ Universitas Kristen Krida Wacana, Jakarta, Indonesia \\ Alamat korespondensi: donna.pasaribu@ukrida.ac.id
}

\begin{abstract}
Abstrak
Terdeteksinya bakteri pencemar pada es batu menunjukkan rendahnya kualitas es batu, yang mungkin berasal dari bahan air, alat yang digunakan dalam pembuatan es, dan kebersihan produsen yang buruk. Pada Peraturan BPOM RI No. 16 Tahun 2016 tentang kriteria mikrobiologi dalam pangan olahan, standar keberadaan Escherichia coli maupun bakteri coliform pada air yang dikonsumsi adalah tidak terdeteksi/250 mL. Kecamatan Grogol Petamburan merupakan lokasi dimana sebagian mahasiswa Fakultas Kedokteran dan Ilmu Kesehatan Ukrida tinggal, oleh sebab itu penulis tertarik melakukan penelitian ini. Penelitian bertujuan untuk mendeteksi ada tidaknya bakteri coliform pada sajian es batu di tempat makan tenda di Kecamatan Grogol Petamburan. Penelitian menggunakan metode studi deskriptif observatif. Sampel yang diambil adalah es batu yang dijual di tempat makan tenda di daerah Kecamatan Grogol Petamburan. Metode TPC (Total Plate Count) dan MPN (Most Probability Number)/APM (Angka Paling Mungkin) digunakan untuk mendeteksi ada tidaknya bakteri coliform. Dari sepuluh sampel es batu yang diambil, didapatkan hasil bahwa seluruh sampel es batu terkontaminasi oleh bakteri coliform dan fecal coliform. Simpulan yang dapat diambil adalah seluruh sampel es batu yang diambil dalam penelitian ini tidak layak untuk konsumsi berdasarkan syarat mikrobiologi yang telah ditentukan.
\end{abstract}

Kata kunci: Angka Paling Mungkin, bakteri coliform, es batu, tempat makan tenda

\section{Determination of Coliform Bacteria Contamination in Ice cube Sold by Street Food Vendors In Grogol Petamburan District}

\begin{abstract}
Bacteria contamination in ice cube may come from poor hygiene process including dirty ice cube maker appliances and the use of unclean water. According to the Indonesian government regulation (BPOM RI No. 16 of 2016 about microbiology criteria for processed food), the standard for Escherichia coli and coliform bacteria content in drinking water is 0/250ml. Grogol Petamburan area is a location where most students of the Faculty of Medicine Ukrida live, therefore the author was interested to do this research. This study aimed to detect the presence of coliform bacteria in ice cube sold by street food vendors. This study used an observational descriptive study method. Ice cube samples were obtained from 10 street vendors in Grogol Petamburan area. Samples were tested based on TPC and MPN methods to detect coliform bacteria. Results showed that coliform bacteria and fecal coliform were detected in all ice cube samples. It can be concluded that all ice samples are not good for consumption according to the microbiological requirements.
\end{abstract}

Keywords: coliform bacteria, ice cube, Most Probable Number, street food.

How to Cite this article :

Dita C, Pasaribu D, Layanto N. Deteksi Bakteri Coliform pada Es Batu yang Disajikan di Tempat Makan Tenda di Kecamatan Grogol Petamburan. JKdoktMeditek;26(2): 60-65. Available http://ejournal.ukrida.ac.id/ojs/index.php/Meditek/article/view/1840 DOI: $\underline{\text { https://doi.org/10.36452/jkdoktmeditek.v26i2.1840 }}$ 



\section{Pendahuluan}

Esherichia coli adalah bakteri dari famili Enterobacteriacea yang memiliki karakteristik sebagai berikut: bakteri Gram negatif batang, bisa bergerak dengan peritrichous flagella atau tidak bergerak, tumbuh di pepton atau media ekstrak daging tanpa penambahan natrium klorida atau suplemen lainnya, tumbuh dengan baik di agar MacConkey, tumbuh secara aerobik atau anaerobik (fakultatif anaerob), memfermentasi glukosa, dapat/tidak dapat memproduksi gas dalam waktu 48 jam pada suhu $35^{\circ} \mathrm{C}$, katalase positif, oksidase negatif (kecuali Plesiomonas merupakan oksidase positif), mereduksi nitrat menjadi nitrit, dan memiliki $39-59 \%$ isi DNA merupakan guanin dan sitosin. ${ }^{1,2}$

Escherichia coli umumnya diakui sebagai flora normal usus manusia dan hewan, meskipun beberapa coliform, termasuk Salmonella, Shigella, dan enteropatogenik Escherichia coli, adalah patogen enterik yang terkenal. ${ }^{3,4}$

Kehadiran coliform dalam makanan dan air, pada umumnya berarti dengan kontaminasi tinja, yang mengakibatkan risiko konsumen terpapar patogen yang menyebabkan bakterimia, infeksi pada luka, dan infeksi saluran kemih, infeksi gastrointestinal seperti diare dan demam tifoid. Penyakit yang berasosiasi dengan Escherichia coli dan seringkali fatal untuk bayi yang baru lahir. Escherichia coli juga merupakan bakteri patogen oportunistik pada neonatal dan pasien dengan penyakit imun..$^{3-6}$

Perjalanan terjadinya penyakit yang diakibatkan oleh Escherichia coli paling sering terjadi karena kurangnya sanitasi dari pengelola air yang akan di konsumsi. Sanitasi lingkungan yang buruk, kebersihan pribadi yang buruk khususnya pada penyaji/ penjual, menyebabkan kontaminasi, kemudian penyimpanan yang tidak tepat mengarah pada penggandaan patogen dalam makanan atau minuman ke dosis infektif., ${ }^{3,5,6}$

Kesulitan pada tatalaksana dari penyakit gastrointestinal yang disebabkan oleh makanan ataupun minuman dikarenakan oleh Escherichia coli sudah banyak dilaporkan. Masalah ini semakin buruk disaat semakin banyaknya kejadian resisten antibiotik, antara lain: carbenicillin, tetrasiklin, streptomisin, norfloksasin, amoksisilin, trimethoprim, nitrofurantoin, asam nalidixic, gentamisin, sefuroxim, dan sebagainya. ${ }^{7-9}$
Berdasarkan BPOM pada tahun 2014, pada pengujian MPN coliform, es merupakan jenis PJAS (Pangan Jajanan Anak Sekolah) yang paling banyak tidak memenuhi syarat, yaitu sebesar 48\%. ${ }^{3,10}$ Belum semua minuman es aman dikonsumsi karena adanya potensi bahaya fisik, kimia dan yang paling banyak dijumpai yaitu potensi bahaya mikrobiologi.

Untuk mengurangi angka kesakitan dan infeksi bakteri saluran cerna akibat mengonsumsi atau menggunakan air yang terkontaminasi fecal coliform, dapat dilakukan pencegahan dengan cara menggunakan sumber air yang dihasilkan oleh suatu alat yang dinamakan Smart water. Produk air yang dihasilkan melalui alat tersebut secara mikrobiologis menurut BPOM layak digunakan untuk konsumsi. Masyarakat atau pelaku industri dapat memanfaatkan teknologi ini, dimana alat Smart water akan menunjukkan indikator bila produk air yang dihasilkan sudah tidak layak untuk dikonsumsi ataupun digunakan. ${ }^{11}$

Secara umum, analisis mikroorganisme pada sampel es yang dikumpulkan mengikuti pendekatan standar berdasarkan jumlah mikrobiologis dan penerapan uji biokimia untuk identifikasi agen patogen utama seperti Escherichia coli, Salmonella sp., Yersinia sp., Pseudomonas aeruginosa, Clostridium perfringens, Shigella sp., Vibrio cholerae dan Aeromonas $s p .{ }^{12}$ Kehadiran spesies patogen oportunistik yang tidak diinginkan lainnya pada es yang dikonsumsi biasanya tidak diselidiki, meskipun es merupakan pangan yang berperan pada penyebaran bakteri yang relevan secara klinis. ${ }^{13}$

Penelitian ini betujuan untuk mendapatkan informasi apakah deteksi bakteri coliform pada es batu yang disajikan di tempat makan tenda di Kecamatan Grogol Petamburan memenuhi syarat standar keberadaan E. coli maupun bakteri coliform pada air dan pangan olahan seperti yang ditetapkan oleh BPOM RI No. 16 Tahun 2016. Hasil penelitian ini diharapkan dapat memberikan informasi ilmiah, kepada mahasiswa Fakultas Kedokteran dan Ilmu Kesehatan Universitas Kristen Krida Wacana (FKIK Ukrida) dan masyarakat sekitar, sebagai salah satu cara untuk mencegah terjadinya penyakit diare. 


\section{Metodologi}

Penelitian ini menggunakan metode studi deskriptif observatif. Sampel yang diambil adalah es batu yang dijual di tempat makan tenda yang berjualan di daerah Kecamatan Grogol Petamburan yang kemudian dibawa ke laboratorium FKIK UKRIDA untuk dilakukan metode TPC dan MPN. Sampel es yang diambil akan dianalisa lebih lanjut untuk mendeteksi ada tidaknya bakteri coliform.

Penelitian dilaksanakan selama empat bulan yaitu dari bulan Februari hingga Mei 2019. Desain penelitian yang dipakai adalah total sampling. Cara pengambilan sampel dilakukan dengan menghitung jumlah warung tenda yang ada di Kecamatan Grogol Petamburan yang buka secara konsisten (setiap hari dari pukul 16.0023.00). Analisis hasil penelitian dilakukan dengan cara obervasi deskriptif, untuk mengidentifikasi bakteri dari sampel es batu yang tumbuh antara lain Escherichia coli. Identifikasi bakteri dilakukan dengan metode API (Analytical Profile Index) 20E, sehingga dapat disimpulkan bahwa isolat bakteri dari es batu terkonfirmasi dengan spesifik adalah coliform (Escherichia coli yang berasal dari lingkungan sebagai sumber kontaminasi) atau fecal coliform (Escherichia coli yang berasal dari tinja manusia sebagai sumber kontaminasi yang tumbuh pada suhu $\left.45^{\circ} \mathrm{C}\right)$.

Saat menggunakan metode TPC, media yang digunakan adalah agar nutrien dalam cawan petri dan diinkubasi pada suhu $37^{\circ} \mathrm{C}$ selama 24 jam dengan posisi terbalik untuk memudahkan mengamati hasil akhir koloni. Total jumlah bakteri yang dianalisis menggunakan TPC pada es batu yang diizinkan sebagai syarat mikrobiologis dari BPOM tahun 2016 sebesar $100 \mathrm{koloni} / \mathrm{mL} .{ }^{14}$ Pada penelitian ini analisa TPC dilakukan dengan metode Pour Plate. ${ }^{15}$ Kemudian untuk uji MPN, dibagi menjadi 3 tahap yaitu uji penduga, uji penegasan, dan uji pelengkap. ${ }^{16}$

Prinsip utama dari uji MPN adalah mengencerkan sampel sampai tingkat tertentu hingga didapatkan konsentrasi mikroorganisme yang sesuai. Hal ini dilakukan agar saat ditanam ke media kaldu laktosa dan Brilliant Green Lactose Bile Broth dapat menghasilkan frekuensi pertumbuhan dari bakteri coliform. ${ }^{14,16}$

Tahap pertama yaitu uji pendugaan dengan menggunakan media Lactose Broth. Pada uji penegasan akan digunakan media BGLB (Brilliant Green Lactose Bile Broth). Pada uji pelengkap menggunakan agar MacConkey. ${ }^{16}$

Dalam penelitian ini juga dilakukan identifikasi bakteri coliform dengan API 20E yang merupakan panel biokimia yang digunakan untuk mengidentifikasi dan mendiferensiasi famili Enterobacteriaceae. ${ }^{17}$

\section{Hasil}

Tabel 1 menyajikan hasil penelitian yang dilakukan di Kecamatan Grogol Petamburan pada bulan Juli sampai Agustus 2019. Dari tabel tersebut terlihat bahwa sampel es batu yang disajikan di tempat makan tenda di daerah Kecamatan Grogol Petamburan dengan metode TPC dan MPN mengandung bakteri coliform.

Dari hasil penelitian pada sampel es batu dapat dilihat bahwa seluruh sampel es batu tidak memenuhi syarat mikrobiologi, baik ditinjau dari hasil uji TPC maupun uji MPN. Seluruh sampel es batu mengalami kontaminasi atau cemaran bakteri coliform. Uji TPC menunjukkan adanya jamur dan bakteri selain bakteri coliform pada agar nutrien. Berdasarkan uji TPC pada seluruh sampel es batu dapat disimpulkan bahwa 10 sampel es batu yang disajikan di Tempat Makan Tenda di Kecamatan Grogol Petamburan tidak memenuhi syarat mikrobiologis dari BPOM 2016 yaitu $100 \mathrm{koloni} / \mathrm{mL}^{14}$ Kemudian estimasi tes MPN dilaksanakan dengan media Kaldu Laktosa, dan Uji Penegasan dilaksanakan dengan media BGLB (Brilliant Green Lactose Bile Broth). Jumlah bakteri coliform dihitung pada uji MPN dilihat dari tabung yang hasilnya positif. Hasil dikatakan positif karena terjadi kekeruhan atau terbentuknya gas dalam tabung durham yang diposisikan terbalik di dalam tabung reaksi. ${ }^{16}$ 
Tabel 1. Hasil Uji TPC, MPN, dan API20E Pada Es Batu Di Rumah Makan Tenda Wilayah Kecamatan Grogol Petamburan

\begin{tabular}{|c|c|c|c|c|c|}
\hline & $\begin{array}{c}\text { Jumlah } \\
\text { cemaran } \\
\text { bakteri } \\
\text { (hasil TPC) }\end{array}$ & $\begin{array}{c}\text { Perkiraan } \\
\text { coliform/ } 250 \\
\text { mL inkubasi } \\
\text { suhu } 37^{0} \mathrm{C} \\
(\mathrm{MPN})\end{array}$ & $\begin{array}{c}\text { Perkiraan } \\
\text { coliform/ } 250 \\
\text { mL inkubasi } \\
\text { suhu } 44^{0} \mathrm{C} \\
(\mathrm{MPN})\end{array}$ & MacConkey & Pewarnaan Gram \\
\hline S1 & 1830 & $>160$ & $>160$ & Merah & Batang, Gram (-) \\
\hline S2 & 25500 & $>160$ & $>160$ & Merah & Batang, Gram (-) \\
\hline S3 & 2460 & $>160$ & $>160$ & Merah & Batang, Gram (-) \\
\hline S4 & 152000 & $>160$ & 24 & Merah & Batang, Gram (-) \\
\hline S5 & 1490 & $>160$ & $>160$ & Merah & Batang, Gram (-) \\
\hline S6 & 10400 & 24 & 24 & Merah & Batang, Gram (-) \\
\hline S7 & 2290 & $>160$ & $>160$ & Merah & Batang, Gram (-) \\
\hline S8 & 2310 & 54 & 54 & Merah & Batang, Gram (-) \\
\hline S9 & 1270 & $>160$ & $>160$ & Merah & Batang, Gram (-) \\
\hline S10 & 150000 & $>160$ & $>160$ & Merah & Batang, Gram (-) \\
\hline
\end{tabular}

Berdasarkan hasil uji MPN dapat disimpulkan bahwa 10 sampel es batu yang dijual kepada konsumen tidak memenuhi syarat mikrobiologi (standar: tidak terdeteksi/250 mL). Uji MPN ini juga dibuktikan dengan identifikasi menggunakan API 20E.

Tabel 2. Kualitas Sampel Berdasarkan Syarat Mikrobiologi BPOM Tahun 2016

\begin{tabular}{|c|c|c|c|}
\hline & $\begin{array}{c}\text { Kualitas sampel } \\
\text { berdasarkan syarat } \\
\text { mikrobiologi ditinjau } \\
\text { dari hasil TPC }\end{array}$ & $\begin{array}{c}\text { Kualitas sampel } \\
\text { berdasarkan syarat } \\
\text { mikrobiologi ditinjau dari } \\
\text { hasil MPN } \\
\end{array}$ & $\begin{array}{c}\text { Tersangka bakteri } \\
\text { (Berdasarkan API 20E) }\end{array}$ \\
\hline S1 & Tidak memenuhi syarat & Tidak memenuhi syarat & Raoultella planticola \\
\hline S2 & Tidak memenuhi syarat & Tidak memenuhi syarat & Escherichia coli \\
\hline S3 & Tidak memenuhi syarat & Tidak memenuhi syarat & Escherichia coli \\
\hline S4 & Tidak memenuhi syarat & Tidak memenuhi syarat & Raoultella ornithinolytica \\
\hline S5 & Tidak memenuhi syarat & Tidak memenuhi syarat & Raoultella ornithinolytica \\
\hline S6 & Tidak memenuhi syarat & Tidak memenuhi syarat & Raoultella planticola \\
\hline S7 & Tidak memenuhi syarat & Tidak memenuhi syarat & Raoultella planticola \\
\hline S8 & Tidak memenuhi syarat & Tidak memenuhi syarat & Raoultella planticola \\
\hline S9 & Tidak memenuhi syarat & Tidak memenuhi syarat & Enterobacter aerogenes \\
\hline $\mathrm{S} 10$ & Tidak memenuhi syarat & Tidak memenuhi syarat & Raoultella planticola \\
\hline
\end{tabular}

\section{Pembahasan}

Pada penelitian tentang perbandingan kualitas es batu di warung makan dengan restoran di DIY pernah dilaksanakan oleh Rahmaniar et al. pada tahun 2011. Hasil perhitungan koloni bakteri pada sampel menggunakan metode TPC dan MPN dan didapatkan hasil jumlah bakteri coliform pada es batu di warung makan sebanyak 17.775 bakteri per $100 \mathrm{~mL}$ (54,3\%), kemudian es batu di restoran sebanyak 14.943 bakteri per 100 $\mathrm{mL}(45,7 \%)$. Jumlah bakteri Escherichia coli pada es batu di warung makan sebanyak 16.439 bakteri per $100 \mathrm{~mL}(54,5 \%)$ dan es batu di restoran sebanyak 13.711 bakteri per $100 \mathrm{~mL}$ $(45,5 \%)$. Penelitian yang telah dilakukan ini 
berbeda dengan penelitian yang telah dilakukan oleh Rahmaniar et al. (2011), karena pada penelitian ini menggunakan 10 sampel es batu dari tempat makan tenda di pinggir jalan. ${ }^{18}$

Penelitian tentang determinasi kontaminasi bakteri coliform pada es batu di Bukittinggi pernah dilakukan oleh Setiawan et al. (2018). Sampel penelitian Setiawan et al. (2018) diambil dari 3 tempat penjual minuman di pasar Aur, kota Bukittinggi. Hasil penelitian menyatakan bahwa ketiga sampel es batu tersebut terkontaminasi oleh bakteri coliform, dimana jumlah bakteri coliform pada sampel A sebesar 1100 bakteri per $100 \mathrm{~mL}$, sampel B sebanyak 1100 bakteri per 100 $\mathrm{mL}$, dan sampel C sebanyak lebih dari 2400 bakteri per $100 \mathrm{~mL}$. Penelitian ini berbeda dengan penelitian yang dilakukan oleh Setiawan et al. (2018). karena pada penelitian ini menggunakan 10 sampel es batu dari tempat makan tenda di pinggir jalan. ${ }^{19}$

Kedua penelitian yang disebutkan diatas menunjukan hasil yang sama dengan penelitian ini yaitu es yang selama ini dikonsumsi masyarakat masih memiliki nilai kelayakan konsumsi, yaitu yang berada dibawah standar kelayakan yang telah ditetapkan oleh BPOM tahun 2016 mengenai air mineral yaitu tidak terdeteksi Escherichia coli per $250 \mathrm{~mL}$ air.

Penelitian tentang jumlah Escherichia coli pada air cucian salada di daerah Grogol Petambuhan Jakarta Barat juga membuktikan bahwa terdapat kontaminasi fecal coliform pada sayuran salada yang dijual di pasar, dimana salada tersebut juga disajikan oleh pedagang di tempat makan tenda di Kecamatan Grogol Petamburan. ${ }^{20}$

Hal ini menunjukkan bahwa kualitas air yang digunakan masyarakat sangat rentan tercemar coliform dan atau fecal coliform. Untuk itu masyarakat dan pedagang di tempat makan tenda di Kecamatan Grogol Petamburan perlu diberikan edukasi penyuluhan untuk menggunakan kualitas air konsumsi sesuai dengan standar BPOM. Salah satu cara pemakaian air yang layak dikonsumsi masyarakat dapat memanfaatkan air yang dihasilkan oleh alat Smart Water. Penelitian ini membuktikan bahwa kualitas air dari mesin Smart Water secara mikrobiologi layak untuk dikonsumsi dan memenuhi syarat BPOM sebagai air minum atau air yang akan dimanfaatkan untuk kebutuhan pangan seperti membuat es batu. ${ }^{11,21}$

\section{Simpulan}

Berdasarkan hasil penelitian dapat disimpulkan, dari sepuluh sampel es batu yang dilakukan uji MPN coliform dan TPC, didapatkan hasil bahwa seluruh sampel es batu telah terkontaminasi oleh bakteri coliform dan koli fekal. Dari sepuluh sampel es batu yang diambil didapatkan 2 sampel es batu terkontaminasi bakteri Escherichia coli, dan didapatkan bahwa seluruh sampel es batu tidak layak konsumsi berdasarkan syarat mikrobiologi.

\section{Daftar Pustaka}

1. Jenkins C, Rentenaar RJ, Landraud L, Brisse S. Infectious diseases enterobacteriaceae. $4^{\text {th }}$ ed. Elsevier. 2017;1565-78.

2. Brooks F, Morse A, Carroll C, Mietzner A, Jawetz BS, Melnick. Adelberg's medical microbiology. 26th ed. New York: McGrawHill Medical. 2013.

3. Nkere C, Ibe N, Iroegbu C. Bacteriological quality of foods and water sold by vendors and in restaurants in Nsukka, Enugu State, Nigeria: A comparative study of three microbiological methods. Journal of Health, Population and Nutrition, 2012;29(6).

4. Mukhopadhyay C, Vishwanath S, Eshwara VK. Introduction: infectious diseases caused by pathogenic bacteria, viruses and parasites are the most commonand widespread health risk associated with drinking water. King Saud Bin Abdulaziz University for Health Sciences; 2012.

5. Schijven JF, Teunis PFM, Rutjes SA, Martijn Bouwknegt, Ana Mariade Roda Husman. QMRAspot: A tool for Quantitative Microbial Risk Assessment from surface water to potable water. National Institute for Public Health and the Environment, Expert Centre for Methodology and Information Services. Bilthoven, The Netherlands. Water Research. 2011;(45:17); 5564-76.

6. Mohamed A.Hamouda, XiaohuiJin, HeliXu, FeiChen. Quantitative microbial risk assessment and its applications in small water systems: A review. Science of The Total Environment. 2018; (15); 993-1002. 
7. Centers for Disease Control and Prevention, National Center for Emerging and Zoonotic Infectious Diseases (NCEZID), Division of Foodborne, Waterborne, and Environmental Diseases (DFWED). Enteric Diseases Epidemiology Branch. CDC's lead epidemiology and surveillance group for tracking pathogens and identifying sources for bacterial enteric (intestinal) infections transmitted by food and other routes. 2018.

8. Felicity C.T.Elder, Edward J.Feil, JasoN.Snape. The role of stereochemistry of antibiotic agents in the development of antibiotic resistance in the environment. Environment International. 2020;(139):105681.

9. Dehbanipour, R., H. Khanahmad, M. Sedighi, A. Zahedi Bialvaei, and J. Faghri. High prevalence of fluoroquinoloneresistant Escherichia coli strains isolated from urine clinical samples. J Prev Med Hyg. 2019;60(1):E25-30.

10. Pasaribu D. Escherichia coli O157:H7 pembawaShiga like toxin. Jurnal Kedokteran Meditek. 2012;18 (46).

11. Centers for Disease Control and Prevention, National Center for Emerging and Zoonotic Infectious Diseases (NCEZID), Division of Foodborne, Waterborne, and Environmental Diseases (DFWED). A Guide to Drinking Water Treatment Technologies for Household Use. 2014.

12. Awuor L, Thompson S, Thompson B, Liberda E, Meldrum R. Microbiological quality and handling practices of ice served in selected downtown Toronto food premises. Environmental Health Review. 2016;59(3):83-7.

13. Gaglio R, Francesca N, Di Gerlando R, Mahony J, De Martino S, Stucchi C et al. Enteric bacteria of food ice and their survival in alcoholic beverages and soft drinks. Food Microbiology. 2017;67:17-22.

14. Kriteria Mikrobiologi dalam Pangan Olahan. Peraturan Kepala Badan Pengawas Obat Dan Makanan Republik Indonesia Nomor 16 Tahun 2016. 2016;49.

15. Making agar plates. [Internet]. University of Utah [cited 12 June 2019]. Teach Genetics Utah. Available from: https://teach.genetics.utah.edu/content/micr obiology/plates/

16. Tristyanto N. Uji bakteriologi MPN Koliform dan Escherichia coli pada air baku kolam renang di Kota Malang. PT Semesta Anugerah. 2018; 7-18.

17. API 20E Test System: Introduction, procedure results and interpretations [Internet]. [cited 11 April 2019]. Available from: https://microbeonline.com/api-20etest-system-introduction-procedure-resultsinterpretations/

18. Rahmaniar SA, Habib I. Perbandingan kualitas es batu di warung makan dengan restoran di DIY dengan indikator jumlah bakteri Coliform dan Escherichia coli terlarut. Mutiara Medika. 2011;11(3):150-8.

19. Budi S, Renatalia F, Mevy T, Ria U. Determination of coliform bacteria contamination on household ice cube in bukittinggi. International Journal of Green Pharmacy. 2018;23.

20. Olianovi, N., \& R.Pasaribu, D. Menghitung Escherichia coli fekal dari air cucian selada di pasar wilayah kecamatan Grogol. Jurnal Kedokteran Meditek. 2017;23(61)

21. Rosadini Pasaribu, D., Arly, F., \& Gunadi, W. (2019). Penilaian Kualitas Air Minum Produk Smart Water Station Berdasarkan Parameter Mikrobiologi Menggunakan Metode Most Probable Number di Fakultas Kedokteran UKRIDA. Jurnal Kedokteran Meditek. 2019;25(2): 66-74. 